\title{
Impacts of Covid-19 on Makhana (Euryale ferox Salisb.) Food Industry in India
}

\begin{abstract}
Background: Makhana or gorgon nut has popular and nutrition rich pop across India and many parts of the world. In the light of the recent makhana food production, there is now considerable concern about the crop management, processing and marketing of makhana pop. Due to Covid-19 spread, many agriculture sectors in India as well as in the World were badly affected because of restriction of movement of workers, changes in demand of consumers and restricted food trade policies and financial instability. Hence, the objective of this present experiment was to assess elaborately about impacts of Covid-19 spread on the production and marketing system of makhana.

Methods: Crop management system was monitored and problems were detected by field visits and taking observations. The sample size was $>10$ at each location for market analysis. Multistage random sampling at each stage and 'Conventional method' were adopted for per cent loss and gain.

Result: According to August-2020 survey, Covid-19 spread and subsequent lock-down situation in India might reduce the total makhana production due to less labor involvement in the production process and would have adverse effect in the marketing system as well as on the export balance in the international market. Accordingly, a case study was also performed from the farmer field of Manigachhi, Darbhanga, Bihar, where crop losses occur from leaf blight due to improper crop management during lock-down situations and they farmers felt an existing weak marketing system. However, during the second survey in November (2020), it was evident that makhana industry got an sudden and impulsive change, due to increase in mass awareness about makhana as a nutrition dense medicinal food and immune booster. Early negative impact of Covid-19 was redressed and finally the makhana food industry became profitable on account of having medicinal and pharmaceutical value.
\end{abstract}

Key words: Covid-19, Loss and gain, Makhana, Marketing, Production.

\section{INTRODUCTION}

Makhana (Euryale ferox Salisb.) is a wonder nut from the wetland ecosystem of India (Jana et al., 2019). It is a nutrient rich dry pop and an excellent source of plant protein, vitamins and minerals (Jana Idris, 2018). Makhana food industry is an agro-based and mostly manual operated (Mandal et al., 2010). Its production process generally starts from Feb (germination) to August/September (harvesting) for processing and subsequent marketing. Bihar is the largest producer of makhana, which contributed $90 \%$ of the total production in the world. Lock down period started on 23.03.2020. Exceptions were remained in the services of essential commodities such as food supplies, medicines etc., in India due to Covid-19 pandemic. Across the globe, cutting across caste and race, we are already witnessing the direct effect of pandemic Covid-19 on agricultural systems due to limiting of human movement and social contact, which resulted in loss of economic and mental vigor in every individual. The state Bihar has a monopoly in makhana production. Bulk of makhana is sold directly either to wholesalers or retailers. Wholesalers themselves purchased the makhana directly from growers, bearing various charges of marketing. According to Sinha (2016), a rough estimate 50,000 tons of makhana worth INR 550 Crores in market are produced annually. In India, makhana exhibits high marketable surplus being a high value cash crop. Household
ICAR-Research Complex for Eastern Region, Research Centre for Makhana, Darbhanga-846 005, Bihar, India.

Corresponding Author: B.R. Jana, ICAR-Research Complex for Eastern Region, Research Centre for Makhana, Darbhanga-846 005, Bihar, India. Email: brjana.ars @gmail.com

How to cite this article: Jana, B.R. (2021). Impacts of Covid-19 on Makhana (Euryale ferox Salisb.) Food Industry in India. Asian Journal of Dairy and Food Research. 40(4): 422-427. DOI: 10.18805/ajdfr.DR-1551.

Submitted: 04-07-2020 Accepted: 14-06-2021 Online: 07-10-2021

consumption of edible makhana is about 1.72 percent of total production. However, wastage was $21.0 \%$ (AFCL, 2007). According to Mr. Hitesh Kumar Mahawar (M. Tech Student, Centre for Technology Alternatives for Rural Areas, IIT Bombay and Mumbai India) estimated at $3.46 \%$ and about $3.55 \%$ of total production was paid as wages and others. Overall, about $88.00 \%$ of the total production among the selected producers was estimated as marketed surplus. High quality makhana pops are pearl white, larger and weigh less and a low-weight bag is thus an indication of good quality. A bag of $8 \mathrm{~kg}$ is an indication of high-quality lava in domestic as well as in international market. Nhava Sheva Sea accounted for $37.1 \%$ of exports followed by Mundra and Sabarmati ICD, which account for $36.7 \%$ and $6.7 \%$ of 
exports to the international market, respectively. In this article, we have discussed negative as well as positive impacts and their effects on different times of the Covid-19 spread transparently by different levels of market analysis from wholesaler to ultimate consumer and citing a case study of a farmer cum pop maker as well as retailer cum whole saler.

\section{MATERIALS AND METHODS}

Market survey was conducted at Darbhanga, Madhubani and Purnia districts of Bihar and field survey regarding cultivation and harvesting was done in Research Centre for Makhana and Farmers' field of Manigachhi, Darbhanga. Reports regarding national and international markets were studied based on reports published in mass media during lockdown periods. A case study was also done from Sh. Ram Chandra Sahani, a producer cum wholesaler from Manigachhi, Darbhanga, Bihar. He usually sells makhana for domestic markets through plastic lining jute/polyester bags ( $8 \mathrm{~kg}$ and $10 \mathrm{~kg}$ ) to Agra, Banaras, Bombay, Joypur, Jodhpur, Kanpur, Kolkata, New Delhi, Patna as well as local district markets of Bihar viz., Darbhanga, Madhubani and Purnia. Regarding prices of makhana in retail markets, data was collected during the year 2020-21 from different stakeholders involved in makhana value chain. For local market analysis, the sample size was $>10$ at each location. In our present study, multistage random sampling was used. From each of the selected districts, the respondent farmers (grower) and retailer were selected. Since the number of makhana wholesalers is very limitted and are dispersed, we considered single big wholesaler as a case study. Firstly, we identified the major marketing channels of makhana. In each stage 'Conventional method' was used for the analysis of market by per cent loss and gain over previous years sold prices.

\section{RESULTS AND DISCUSSION}

In this present article, we are discussing about demand and supply of makhana during lock down situation from north Bihar. There was a discussion about short term and long term affects of covid-19 pandemic.

\section{Short-term impacts}

Makhana production and processing involved in a lot of drudgery and laborers. Covid-19 spread restricted communications and attachments of laborers to this industry. Production and processing were hampered and unsatisfactory. FAO has a forecast for decreasing food production and reduction in sustainable agricultural production (FAO, 2020). Makhana crop has already been established under the pond system of cultivation. But in the case of field cultivation, which just began with monsoon water for late season crops (Kumar et al., 2011). The problems of laborers and capital investment may occur in the field system of cultivation but its acreage and production are very less. However, the workforce involved for intercultural operations for makhana crops was not intensive. After establishment of makhana crop, harvesting and processing are cumbersome processes but it can be performed by maintaining social distancing and other restrictions. Obviously, harvesting of fresh makhana crops could be impaired the scarcity of laborers. During the lockdown period laborers were not seriously engaged in work and their mental energy for hard work has been changed. Therefore, the cost of production would have more. Makhana cultivation/transplantation with rainwater under low land conditions during July may get disturbed and management of crops would be hampered/affected. Most of the makhana growers in Bihar are connected with SHG (Self-help group) and due to lock down situation they could not communicate themselves efficiently which resulted in not following proper cultivation practices. Makhana harvesting and processing may not be disturbed if laborers and technical people may perform all processes by maintaining social distancing, sanitization, etc. in future. According to earlier assumptions (August 2020), makhana production regarding processing and marketing may face serious problems as the market was not fully opened so far and somewhat weak (Stephens et al., 2020).

\section{Long-term impacts}

Makhana has very good international markets in Australia, Middle East Countries, New Zealand, Singapore, UK and USA. In India, makhana are mainly consumed in Ahmedabad, Bombay, Delhi, Hyderabad, Jodhpur, Joypur, Kolkata Kanpur, Lucknow and Varanasi. Marketing processes both in the domestic and international arena are definitely restricted but to what extent that could not be exactly predicted now. Farmer's income/margin of net profit may be reduced due disrupted works caused by Covid-19 spread. International export of makhana pop and other processed products of 2016 was net worth of 5.2 million USD (Anonymous 2016). By and large, we conclude that pop makhana trade would be diminished to some extent (Stephens et al., 2020) and affected during 2020. According to global news 2020, the impact of novel coronavirus pandemic on the fox nut (makhana) market, there will be definite market fluctuations during the forecast period of 2018-2040 (Global News, 2020). Farmers/makhana growers will definitely get lower prices which will certainly decrease their standard of living. Domestic market of makhana can improve the situation. As early monsoon in 2020, gave heavy downpour, the overall makhana production was increased in this year despite of Covid-19 spread. Under the standard of protocol, the government allows operations of suppliers of essential goods including restaurants for home delivery and go-downs for storage of essential goods, transporters, etc. for transfer of essential goods from producers to retailers. Survivals of start-ups in the present pandemic era, dealing in food and beverage products have become a big concern due to clouds of confusions about guidelines. There was no clarity on the food producer and supply of makhana food products but they, being ancillary, should be treated at par food products. Indian Govt. also announced a lot of funds to improve makhana production in Bihar particularly to 
inspire the poor farmers for more income or improve farm economy although some problems still exist (Sally, 2020).

According to two consecutive surveys in the markets of north Bihar and a case study, we got affirmative information about changes in marketing systems of makhana during Covid-19 spread and during different months of year 2020. In this article, we are discussing all the facts under following heads:

\section{Supply chain of pop makhana in Bihar and distant markets}

Makhana is high value cash crop from wetland ecosystem of India. Makhana sector has created more than 40,000 employment opportunities (Minten et al., 2012) in Northern Bihar, West Bengal and Assam. The fisherman community is mainly involved for cultivation of this crop. In India, Bihar has almost gained monopoly in production of makhana, According to a report, more than 15,000 MT of Makhana pop is traded annually (Micro, Small and Medium Enterprises Development Institute, 2016). However at grass root level/ agronomic producer level Makhana generates revenue of less than 250.00 crore annually (Sandeep et al., 2015 and NRCM 2003). In India, four systems of Makhana marketing are exist. In first system, farm gate sale of makhana seeds to collector or aggregators. Whereas in second systems farmers sold raw Makhana seeds directly to the processors. In third system farmers processed the makhana seeds into pops and sold it to the local wholesalers. In final stage (Fourth system) wholesaler sales the produce for distant markets by growing and making pop.
Covid-19 spread had no impact on farm gate sale of the produce (makhana seeds). In normal case, the annual gains in second and third system are $15.0-16.0 \%$ and $22.0-$ $25.0 \%$, respectively. During lockdown period in 2020 , the seed/pop prices were increased up to $18-20 \%$ in second system and $30.0-33.0 \%$ in third system of marketing channel. When a farmer was a wholesaler then profit gone up to $50-60.0 \%$ in 2019 and $70-80 \%$ in 2020 , respectively [base year 2018-19, base value of makhana seed is $90.00 / \mathrm{kg}]$. It has been found that direct supply of seeds to the processer and direct popping by farmers and direct marketing by wholesaler (Fourth channel) earned more during 2020 (Fig 1).

After processing polishing of pop are accomplished. High quality makhana pops are pearl white and larger. Thus, low-weight bags are an indication of good quality. A bag of $8 \mathrm{~kg}$ is an indication of high-quality lava in domestic as well as in international markets. According to Minten et al. (2012), the state, Bihar, has a monopoly in makhana production. Bulk amount of makhana is sold directly either to wholesalers or retailers by the farmer. As per a rough estimate, annually, 50,000 tons of makhana worth INR 550.00 crores are usually marketed (Sinha, 2016). Household consumption in Bihar are less, however, wastage was recorded at about $21.0 \%$ (AFCL, 2007) annually. During lock down period almost all makhana pops were sold by the farmers. Few wholesaler and retailers may store the makhana pops for future disposal according to November (2020) survey.

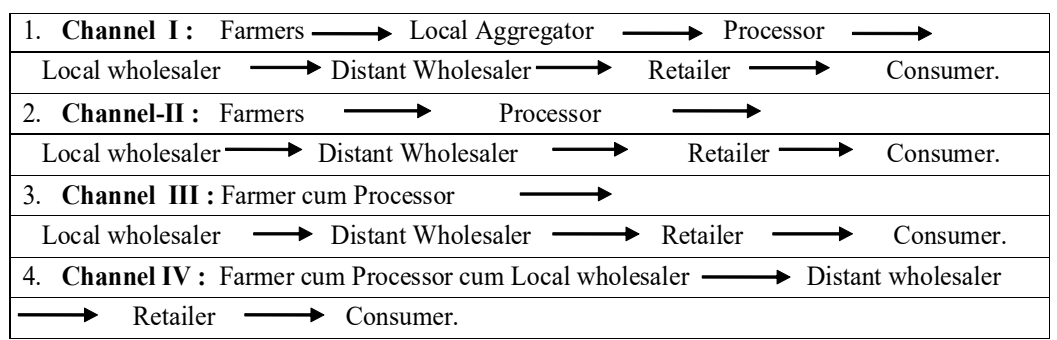

Fig 1: Different Makhana marketing channels existing in Bihar (2020-21).

**** If farmers adopted a higher channel for marketing of their products, they obviously get higher returns.

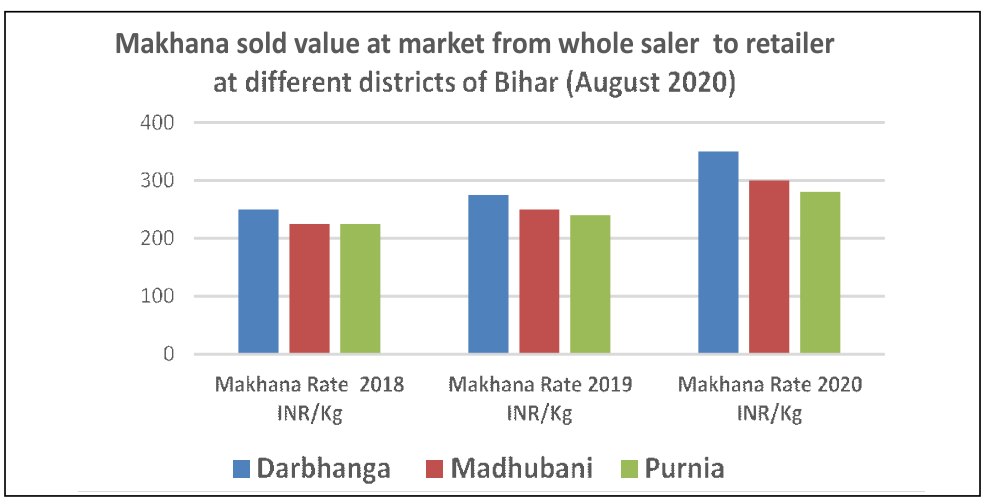

Fig 2: Pop Makhana prices at different districts of north Bihar from August survey. 
COVID-19 impact on demand and supply chain (AugustNovember, 2020): A case study

According to the opinions of the grower of makhana and our research, this year production of raw material (Seeds/ guri) was more than that of previous year due to favourable rainfall. Due to Covid-19 spread and agronomic mismanagement some of the fields of makhana were affected by Jhulsha disease (leaf blight), therefore Mr. Ram Chandra (farmer) did not promise for higher supply to retailers at distant markets. In spite of his farm production, he procured makhana seed from other parts of Bihar and West Bengal. Earlier reports on makhana markets in Bihar revealed that in the open market for ultimate consumers, the makhana rate was @ INR 450.00-500/ kg. But retailers rate was a little bit low (275.00-350.00/ kg) (Fig 2). We surveyed the markets of Madhubani, Darbhanga and Purnia during August, 2020 when new crops came into the market. Now in November demand for makhana in the domestic market has been increasing steadily. The rate of makhana is gaining more nowadays. Makhana rate to the ultimate consumer is now INR 500.00-600.00 INR/kg at Darbhanga local markets. In open market and retailers the rate from the whole seller is increased from INR 350.00-450.00, even to INR 500.00/kg now. Due to medicinal and immune boosting properties, this crop showed a sudden increase in its consumption in the national markets. This phenomenon may pave the way for higher exports to the international market later on. Initial demand for makhana in local as well as distant markets was low as compared to 2019 (Fig 3). But due to mass awareness in October and November, demand in the local as well as distant markets (inter-state) has been increased. Up to December 2020, the total demand of pop makhana increased for the distance markets and it was about 7.5 tons and for the local market was about 3.0 tons to big wholesaler, Sh. Ram Chandra Sahani (Manigachhi, Darbhanga, Bihar). For the distant market, he received an order of total 7.5 tons of makhana before August 2020 but now he is requested to send more (total 9.0 tons) (Fig 5). Keeping space with the recent demand, ultimate sale price to consumers is also increasing from INR $450.00 / \mathrm{Kg}$ to INR600.00/kg (Fig 4) (December 2020) at Darbhanga, Bihar.

Future constraints according to August (2020) assessment/ survey

1. Makhana is a non-perishable crop that can be stored for long times, therefore, market glut and improper marketing system could not be appeared.

2. As of now, disruptions are minimal as makhana food supply has been adequate. There is less consumption of food from high-value commodities (i.e. fruits and vegetables and nuts), therefore, related food industry could not be suffered a lot.

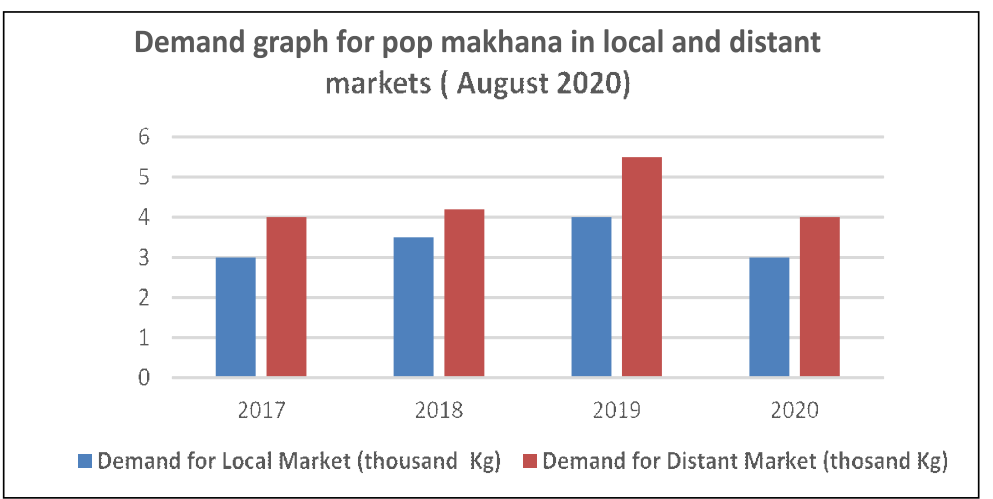

Fig 3: Demand graph of pop makhana from single producer cum pop wholesaler at Manigachhi, Darbhanga, Bihar.

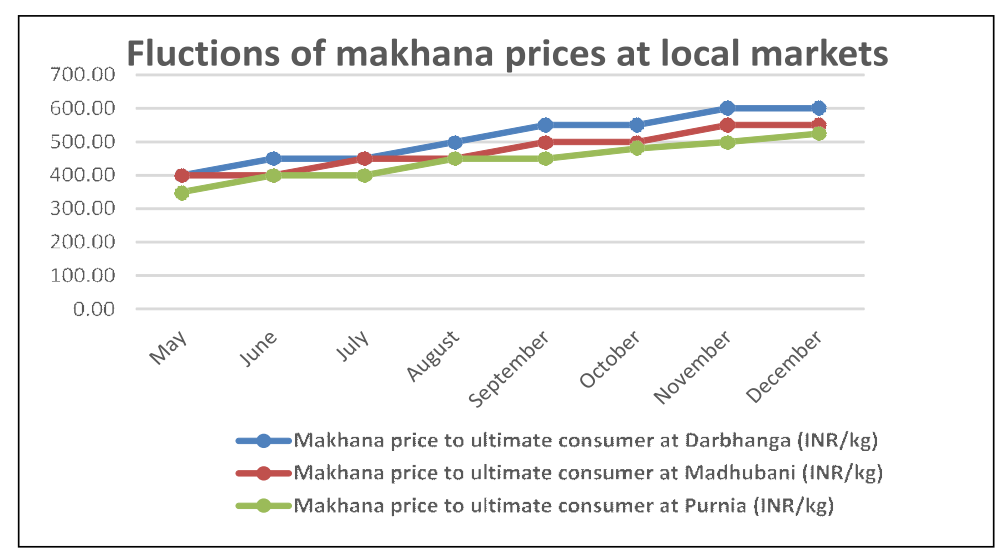

Fig 4: Makhana prices at different local markets of North Bihar. 


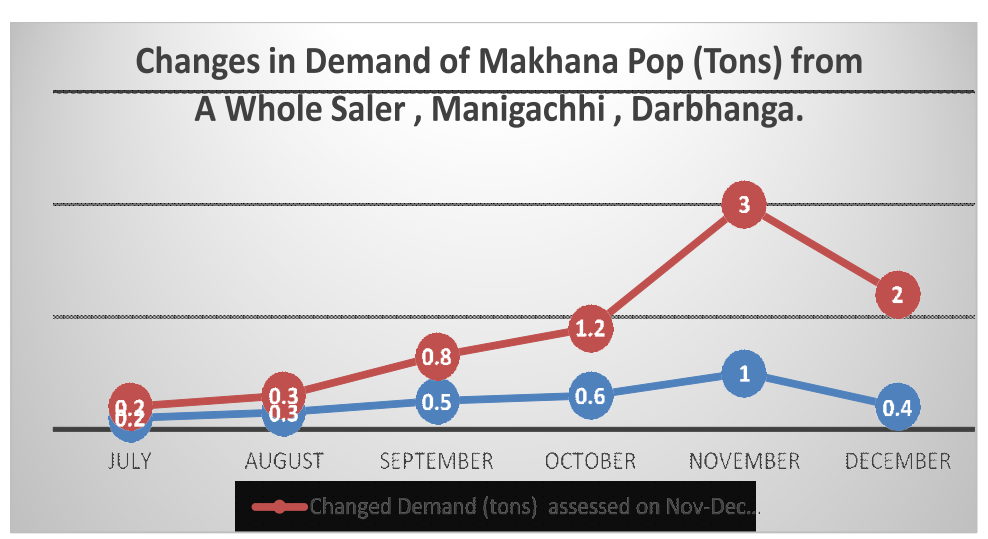

Fig 5: Changes in total demand of makhana at the local and distant markets.

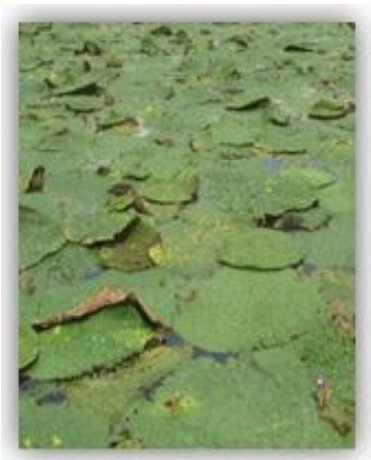

Fig 6: Makhana at pond.

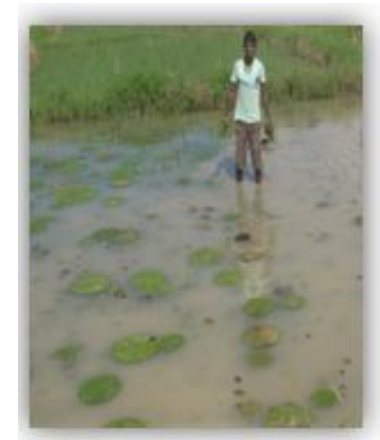

Fig 7: Monsoon water and makhana at field

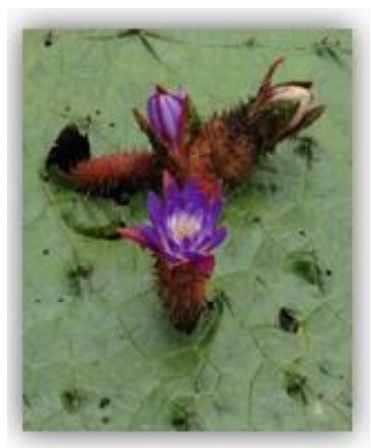

Fig 8: Makhana flowers and fruits.

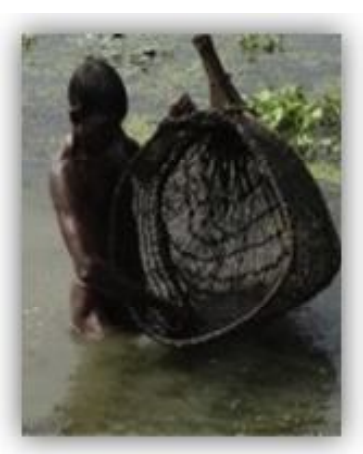

Fig 9: Makhana harvesting

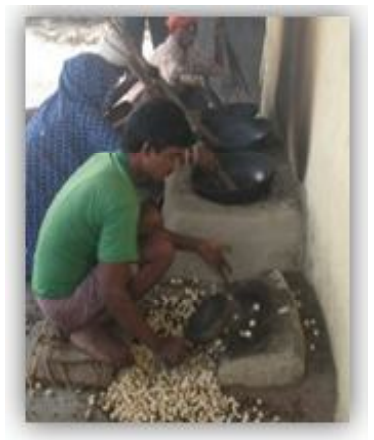

Fig 10: Makhana lava making (Manual).

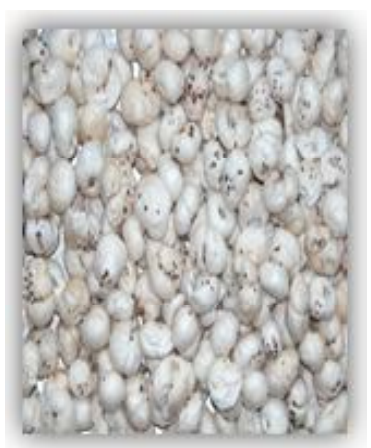

Fig 11: Packaging of makhana pop.

Photographs of makhana crops and processing (Fig 6-11) during Covid-19 infestation in India. 
3. Poor makhana farmers also might face challenges accessing markets to sell their products or struggle due to higher food prices and limited purchasing power.

4. Lot of laborers are involved in makhana seed production chain. Shortages of laborers due to fear from Covid-19 pandemic could disrupt production and processing of makhana food in future.

5. Loss of income-earning opportunities of Indian people could affect demand and consumption of makhanaprocessed food.

\section{Recent advancement according to November (2020)} assessment/survey

1. Only, due to medicinal properties and increased mass awareness makhana food industry become profitable now (November, 2020) even under post lock down situation.

2. The phenomenon of 'the spread of Covid-19' has ultimately alleviated the status of the makhana food industry towards country people.

\section{CONCLUSION}

New entrepreneurs for makhana cultivation and processing for the year 2020 were interrupted and faced troubles. Existing makhana industry got somewhat disruption in early this year. According to the August (2020) survey, the concept was that if domestic and international markets remain viable and monsoon remains satisfactory for the rest of the months, then the makhana food industry would survive. Covid-19 cases were increasing fast in Bihar and there were great concerns and negative impacts on sustainable makhana production, supply chain and makhana food industry. However, at the end of October, it has been found that more availability of labour reduced the production cost at processing level. The demand for makhana as a medicinal food has also been increased. Due to Covid-19, makhana have been well recognized towards people, the ultimate consumer, as a nutrition rich medicinal super food.

\section{Conflict of interest}

Author declares that there was no conflict of interest.

\section{REFERENCES}

Agricultural Finance Corporation Ltd. (2007). Project Report on Export Promotion of Makhana from Bihar under GolUNCTAD DFID; Project on strategies and preparedness for trade and globalization in India.
Anonymous. (2016). Makhana export from India. www.connec2india. $\mathrm{com} / \mathrm{global} / \mathrm{makhana}$ export from India.

F.A.O. (2020). Agri-food markets and trade policy in the time of COVID-19. 2 April 2020; Agrilinks, Preventing Global Food Security Crisis under COVID-19. 18 March 2020.

Jana, B.R., Srivastava, A. and Idris, Md. (2019). New makhana (Euryale ferox Salisb) processed products for health benefit. Journal of Pharmacognosy and Phytochemistry. 8(2): 1662-1666.

Global News. (2020). The potential impact of coronavirus (COVID19) for fox nuts (Makhana) market: Industry trends and development, 2018-2040 May-24, $2020 \mathrm{https} / / / \mathrm{www}$. marketresearchhub.com/enquiry. php?type=s \&repid $=2673498 \&$ source $=$ atm .

Jana, B.R. and Idris, Md. (2018). Anti-aging amino acids in Euryale ferox (Salisb.). Advances in Plants and Agriculture Research. 8(1): 43-48. DOI: 10.15406/apar.2018.08.00 289.

Kumar, L., Gupta, V.K., Khan, M.A. and Singh, S.S., Janardan, J. and Kumar, A. (2011). Field based makhana cultivation for improving cropping intensity of rice fields. Bihar Journal of Horticulture. 1(1): 71-72.

Mandal, R.N., Saha, G.S. and Sarangi, N. (2010). Harvesting and processing of makhana (Euryale ferox Salisb.)-An unique assemblage of traditional knowledge. Indian Journal of Traditional Knowledge. 9(4): 684-688.

Minten, B., Singh, K.M., Sutradhar, R. (2012). Branding and Agricultural Value Chains in Developing Countries. Insights from Bihar, India, 11/33, International Food Policy Research Institute (IFPRI), New Delhi, India.

Stephens, E.C., Martin, G., Wijk, M.V., Timsina, J. and Snow, V. (2020). Impacts of COVID-19 on agricultural and food systems worldwide and on progress to the sustainable development goals. Agric Syst. 183: 102873. doi: 10.1016/ j.agsy.2020.102873.

Sally, M. (2020). Finance minister Nirmala Sitharaman rolls out a Rs 10,000 crore scheme for food processing sector, ET Bureau, May 15, 2020, 06.40 PM IST.

Sinha, S.P. (2016). A study on dynamics of marketing of selected fruits in Bihar. Bihar Institute of Economics Studies, Patna, Bihar, India http://agmarknet.nic.in/resproj3.htm\# Project5 (Last accessed: 22/10/2016)

Sandeep, K., Sehrawat, R., Kumar, A., Basir, K., Prakash, K.S. (2015). Effect of different grades on physical and mechanical properties of popped mkahana. Int. J. Processing and Post Harvest Technology. 6(1): 101-108. 